\title{
RUB A LÍC REPREZENTACE ŠVIHOVSKÝCH Z RÝZMBERKA NA PŘELOMU GO- TIKY A RENESANCE
}

\author{
JIŘÍ VARHANÍK
}

\begin{abstract}
Abstrakt: Švihovští z Rýzmberka byli objednateli četných kvalitních uméleckých děl. V literatuře se v této souvislosti někdy vyskytuje značně nadsazené hodnoceni jejich stavebni produkce, zejména opevnění jejich hradů Švihova a Rabí. Úroveň těchto staveb však nevyznívá zcela jednoznačně a není prosta někdy až zarážejicich protikladì.
\end{abstract}

Klíčová slova: hrad-opevnění-kaple-sanktuárium-pozdni gotika-renesance.

The Pros and Cons of the Representation of the Švihovský of Rýzmberk Family between the Gothic and the Renaissance

Abstract: The Švihovskýs of Rýzmberk commissioned numerous artworks of high quality. In this respect, specialist literature occasionally brings somewhat overrated assessments of their constructions, especially the fortifications of the Švihov and Rabi castles. Yet the standard of these structures is not completely flawless and manifests some striking controversies.

Key words: castle - fortification - chapel-sanctuary-late Gothic-renaissance.

Dílům výtvarného umění, jejichž objednavateli byli příslušníci předního západočeského panského rodu Švihovských z Rýzmberka na přelomu pozdní gotiky a nastupující renesance, byla věnována již dříve $\mathrm{v}$ literatuře značná pozornost a nedávno se toto téma dočkalo intenzivního interdisciplinárního zájmu v souvislosti s výstavou Gotika v jihozápadních Čechách (Jindra-Ottová 2013).

Půta Švihovský z Rýzmberka († 1504) zahájil velkorysou přestavbu dvou nejvýznamnějších rodových hradů, Švihova a Rabí, přičemž na obou vybudoval nové kaple. V budování opevnění těchto hradů pokračovali jeho synové. Švihovští z Rýzmberka byli v uvedeném období objednateli četných kvalitních uměleckých děl, z nichž je zřejmě nejznámější Půtův nádherný figurální náhrobek z červeného mramoru v klášterním kostele v Horažd’ovicích (Chlíbec 1983; Chlíbec-Roháček 2011, 127-137). Patrně pod tímto dojmem se někdy vyskytuje značně nadsazené hodnocení jejich stavební produkce, zejména opevnění obou uvedených hradů. Při poněkud stř́izlivějším pohledu však úroveň staveb budovaných Švihovskými z Rýzmberka nevyznívá zcela jednoznačně a není prosta leckdy až zarážejících protikladů. Př́íspěvek v tomto kontextu hodnotí některé znaky úrovně architektury obou jejich předních sídel v kontextu dobové tvorby a všímá si některých převážně opomíjených aspektů stavební kultury ve službách významných členů panské oligarchie na přelomu 15. a 16. století.

V souvislosti s poměrně početnými artefakty sakrální povahy, které byly Švihovskými z Rýzmberka pořízeny, je na místě věnovat pozornost hradním kaplím jejich sídel. Starší je kaple na Švihově, svěcená v roce 1489 (Pešina 1954; Lancinger-Muk 1975, 89-93; Záruba 2013a). Vlastní prostor kaple zaujímá horní část rozměrné budovy, připojené na východní straně k hradbě jádra hradu. Půdorys obdélného objektu s polygonálním závěrem, který se výškou rovnal oběma palácům, se podřizuje uspořádání kaple, přičemž jeho východní část předstupuje jako bašta do př́kopu před linii parkánu. Exteriér budovy je poměrně strohý, spodní nečleněná část tvoří podnož kaple. V úrovni sklepa se otvírala navenek příčně obdélnými střílnami a osovým sedlovým portálkem, v úrovni přízemí pak obdélnými okénky. Výpadní branka byla zazděna zřejmě v souvislosti s vybudováním vnějšího okruhu opevnění v těchto místech. Poněkud ustupující průčelí kaple jsou členěna mělkými neodstupněnými opěráky, částečně konzolovitě vyloženými před úroveň líce zdiva spodní části stavby. Kapli osvětlují hrotitá okna s poměrně hlubokými špaletami s dvojdílnými kružbami vrcholícími trojlistem.

Jednolodní interiér kaple byl zaklenut hvězdovou klenbou, jejížžebra se nedochovala. Kruchta v západní části kaple je podklenuta obkročnou klenbou. Hrotité arkády, jimiž se podkruchtí otvírá do kaple, jsou zdobeny kraby a křižovými kytkami ve vrcholech. Předprseň kruchty je 


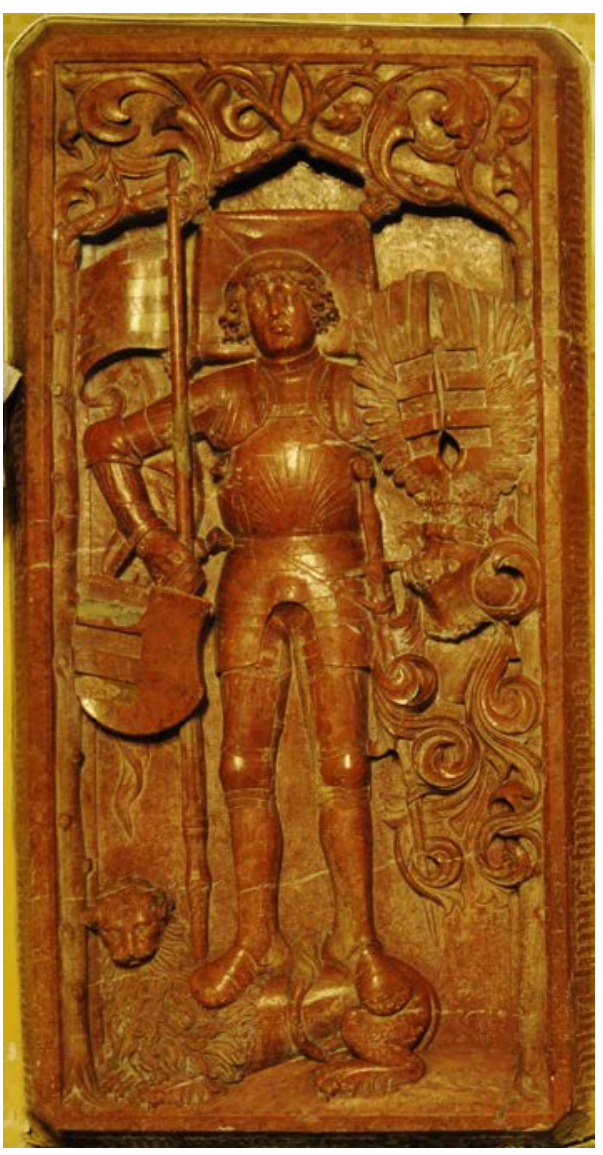

Obr. 1. Náhrobek Půty Švihovského z Rýzmberka v klášterním kostele v Horažd'ovicích. Foto J. Varhaník, 2015. Abb. 1. Grabplatte von Puta Schwihau von Riesenberg in der Klosterkirche in Horažd'ovice. Foto J. Varhaník, 2015. členěna panelováním, krajní dvojice polí vyplňují malované kružby, středních pět pak erby. K severní stěně presbytáře přiléhá kamenné sanktuárium, $\mathrm{v}$ protikladu $\mathrm{k}$ poměrně bohaté výzdobě kruchty provedené nápadně skromným způsobem jen s drobným štítkem se znakem Švihovských. Jednoduchá architektura sanktuária hradní kaple podivně kontrastuje $s$ relativně bohatě členěným sanktuáriem kostela v Nezamyslicích nedaleko Rabí, nesoucím kolčí štíty s erby Půty Švihovského, jeho manželky Bohunky Meziříčské z Lomnice a Zachaře z Opatovic, purkrabího na Rabí v letech 1488-1509 (Hostaš-Vaněk 1900, 78; Mudra 2013, 150-151; Červenka 2015, 45-47), které je zdobeno početnými fiálami s kraby. Podle J. Muka sanktuárium švihovské hradní kaple nesnese srovnání se současnými díly v jižních Čechách i jinde (Lancinger-Muk 1975, 151).

Portál švihovské hradní kaple zhodnotil již dříve V. Mencl $(1960,144)$. Poukázal na skutečnost, že jde ještě o předhusitský typ, u něhož se pruty ostění nikde neprotínají. Za pokročilejší považoval pouze tympanon, utvářený jako trojlist na masivních konzolách, opatřený ve spodní části subtilním, volně rozepjatým dvojlistem s maskaronem. Avšak i v utváření maskaronu autor shledává inspiraci $\mathrm{v}$ poklasické gotice 14. století. Pro úplnost je třeba dodat, že právě tento střední díl volné, poněkud rozpačitě rozvržené kružby s mělkým reliéfem maskaronu je novodobou kopií, zatímco originál je bohužel zřejmě nenávratně ztracen.

V případě Rabí o hradní kapli v pravém slova smyslu nejde, nebot' na sklonku 15. století nově vybudovaná svatyně především plnila funkci kostela pro podhradí. Paradoxně však není součástí městečka založeného Půtou Švihovským, ale poněkud výše položeného staršího osídlení na úpatí hradu zvaného Hradčany (Pelant 1988, 237-238), které lze vzhledem k jeho podobě nejspíše charakterizovat jako latrán (Varhaník 2010, 42). Pouze tato část podhradí byla ohrazena, přičemž budova kostela byla do jeho východní části zapojena tak, že presbytář předstupoval před hradbu. Jeho suterén na klesajícím terénu měl podobně jako na Švihově podobu bašty, ovšem podstatně skromněji vybavené. Polygonální závěr presbytáře člení drobné jednou odstupněné opěráky vyrůstající z ústupku nad suterénem. Exteriér poněkud širší lodi je velice strohý, bez jakéhokoli plastického členění. Jak presbytář, tak lod' osvětlují poměrně úzká hrotitá okna s jednoduchými dvoudílnými kružbami s poněkud mělčími špaletami než na Švihově, nebot' tloušt'ka zdiva je zde menší. Interiér připomíná švihovskou kapli svým rozložením do šířky, které je v lodi ještě zdůrazněno vtaženými pilíři sítové klenby, jejíž žebra vybíhají ze stěn bez konzol. Průniky žeber zdobí štítky s heraldickými motivy. Sítová klenba se uplatňuje též v presbytáři, kruchta $\mathrm{v}$ západní části lodi je přístupná šnekovým schodištěm v jihozápadním koutě, které stoupá až do půdního prostoru.

Jak konstatovali již dříve autoři stavebněhistorického průzkumu objektu, úroveň architektury kostela nevybočuje z pozdně gotického průměru (Lancinger-Líbal-Muk 1974, 26). Naproti 


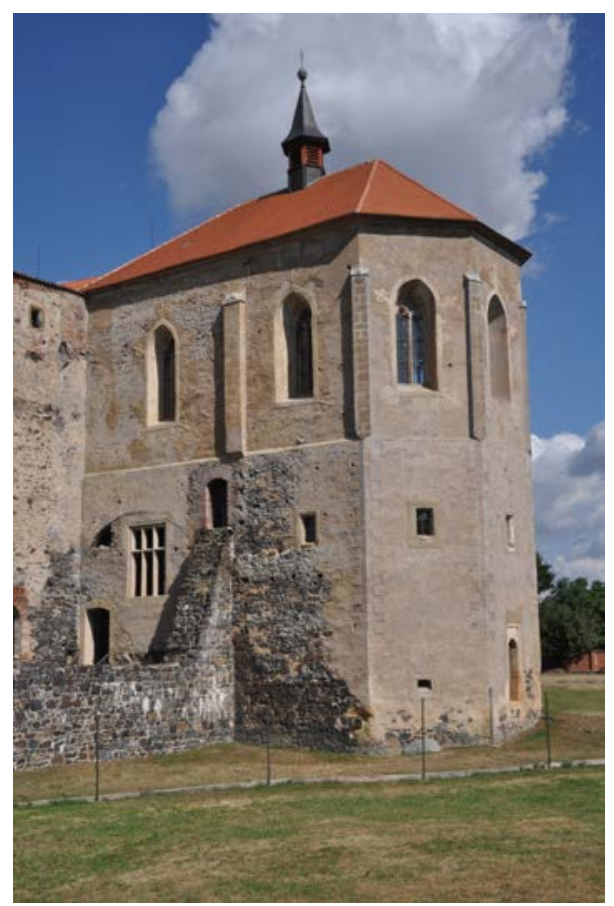

Obr. 2. Hrad Švihov, okr. Klatovy. Pohled na křídlo s kaplí. Foto J. Varhaník, 2015.

Abb. 2. Burg Schwihau, Bezirk Klatovy. Blick auf den Flügel mit Kapelle. Foto J. Varhaník, 2015.

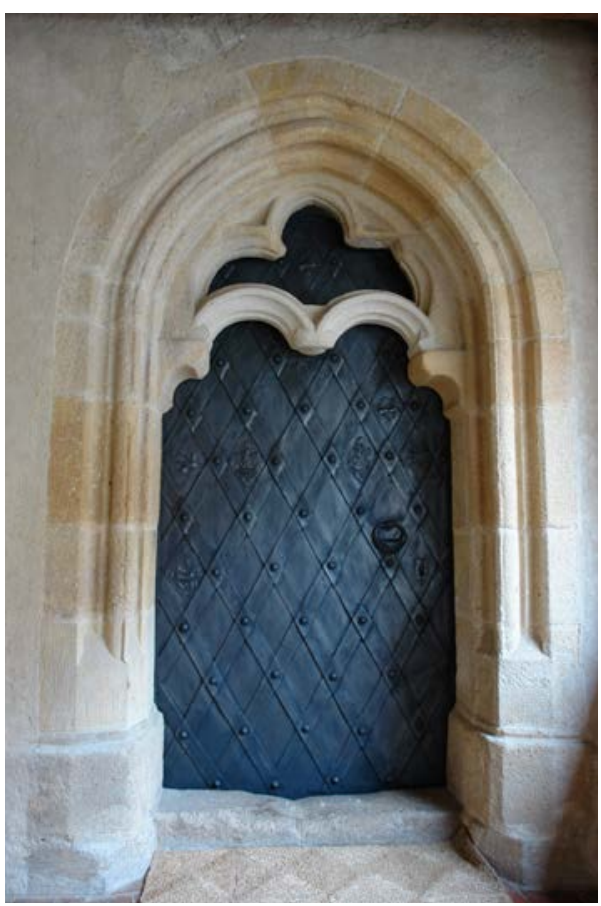

Obr. 3. Hrad Švihov, okr. Klatovy. Portál hradní kaple. Foto J. Varhaník, 2015.

Abb. 3. Burg Schwihau, Bezirk Klatovy. Portal der Burgkapelle. Foto J. Varhaník, 2015.

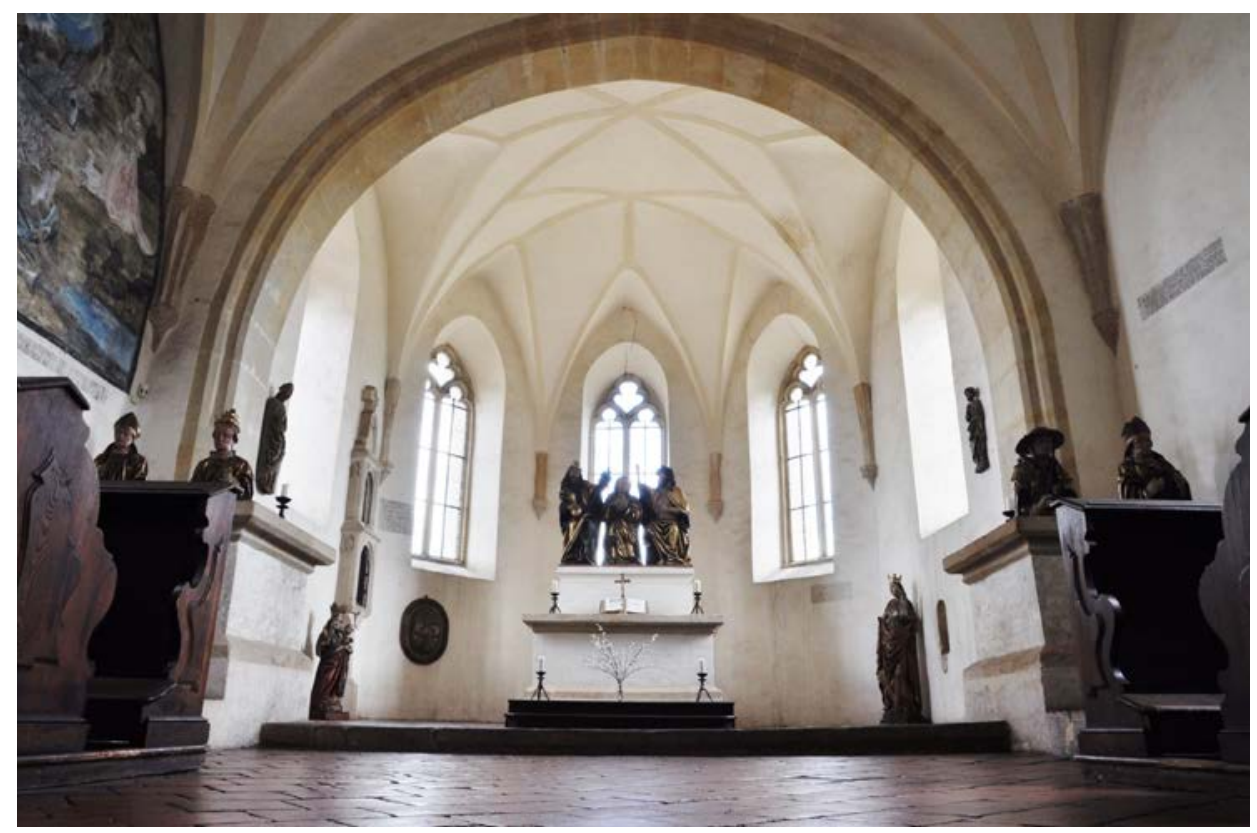

Obr. 4. Hrad Švihov, okr. Klatovy. Interiér hradní kaple. Foto J. Varhaník, 2015.

Abb. 4. Burg Schwihau, Bezirk Klatovy. Innenraum der Burgkapelle. Foto J. Varhaník, 2015. 


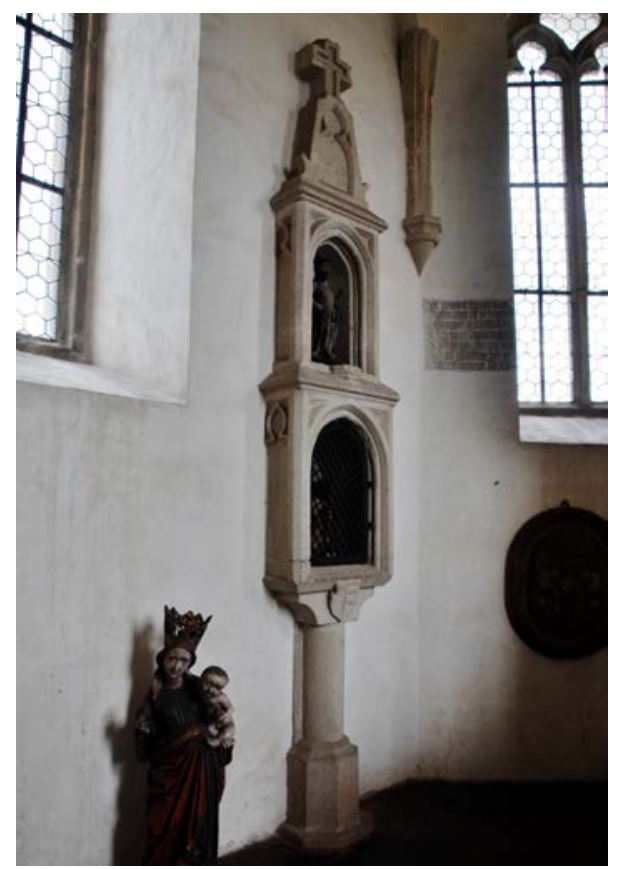

Obr. 5. Hrad Švihov, okr. Klatovy. Sanktuárium v hradní kapli. Foto J. Varhaník, 2015.

Abb. 5. Burg Schwihau, Bezirk Klatovy. Sakramentshäuschen in der Burgkapelle. Foto J. Varhaník, 2015. tomu vybavení kostela zřejmě bylo velice bohaté (Ottová 2013, 271-274). Peter Kováč $(1989,296)$ si již dříve v této souvislosti položil otázku, jakým dojmem asi zapůsobila Půtova hradní kaple na představitele české šlechty, kteří se na Rabí sešli v roce 1502 . V této souvislosti je třeba uvést, že na emporu v lodi se scházelo z ochozu hradby přihrádku, avšak nikoli přímo (Varhaník-Krušinová-KynclKyncl 2005, 63). Uvedení příslušníci české aristokratické elity tedy při návštěvě kostela museli absolvovat cestu po můstku, po jehož překonání vešli do půdního prostoru lodi, z něhož však nebyl za tímto účelem vydělen žádný zvláštní koridor, a odtud sestoupili šnekovým schodištěm na emporu, odkud teprve mohli obdivovat vybavení kostela. Provoz této poměrně složité, a nikoli právě reprezentativní komunikace usnadňovala trojice okének v západním štítu lodi osvětlující její úsek mezi dnes zazděným vstupem $\mathrm{z}$ můstku a šnekem $\mathrm{v}$ jinak temném prostoru krovu kostela. Je pozoruhodné, že toto řešení do určité míry předjímalo pozdější kryté, často velice dlouhé chodby do sakrálních objektů (Bláha 2010; Kašička 2011; Varhaník 2015).

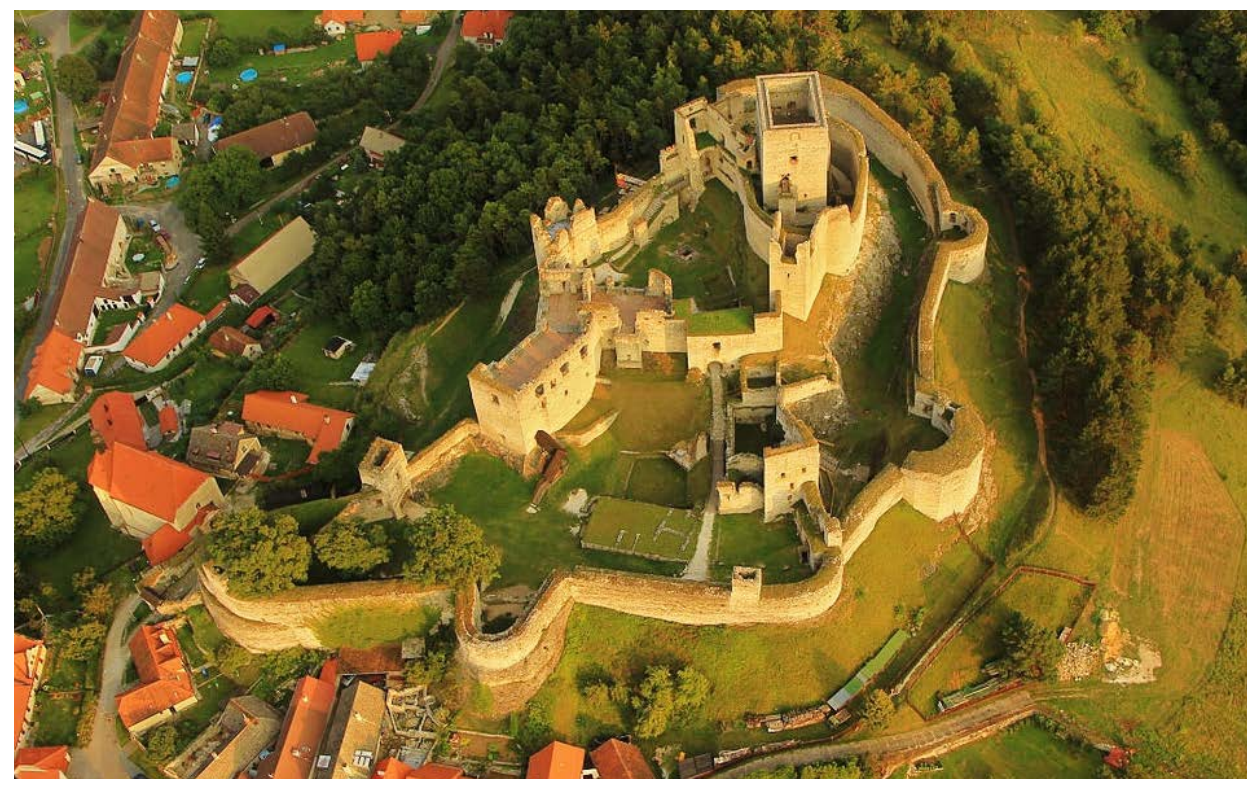

Obr. 6. Hrad Rabí, okr. Klatovy. Letecký pohled od severozápadu. V popředí část vnějšího opevnění komponovaná na renesančním půdorysu podle stř̌ední osy, od níž se odchyluje velká střední bašta. Foto archiv J. Varhaníka.

Abb. 6. Burg Rabí, Bezirk Klatovy. Luftansicht aus Nordwesten. Im Vordergrund der auf dem Renaissancegrundriss entlang der Mittelachse komponierte Teil der äußeren Befestigung, von dem sich die große Mittelbastei abhebt. Foto Archiv J. Varhaník. 
Architektura kaplí obou hradů je v žádném př́ípadě nedovoluje považovat $\mathrm{v}$ dobovém kontextu za výjimečné sakrální prostory, jak uvádí M. Ottová $(2013,274)$.

Dochované bašty a věže švihovského opevnění jsou opatřeny stř́lnami různého tvaru s převážně tesaným ostěním (Menclová 1972, 405; Lancinger-Muk 1975, 99-100, 105, $113,120,128)$. Podoba zbořené části švihovského opevnění je známa především z vyobrazení hradu v kapli, podle něhož byla opatřena klíčovými a štěrbinovými stř́ílnami. Podle analogií lze usuzovat, že zatímco lomové zdivo z demolice mohlo být převážně použito k zasypání příkopu, použitelné prvky, mezi

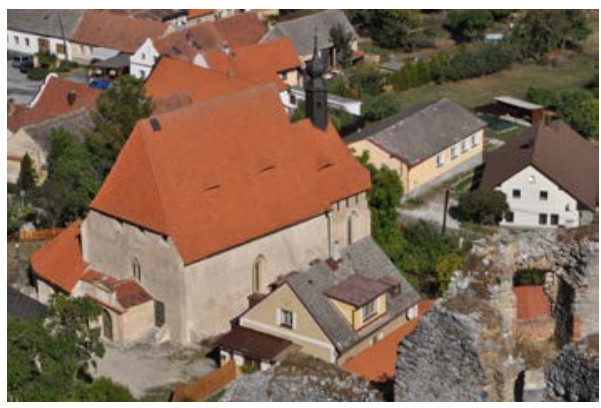

Obr. 7. Rabí, okr. Klatovy. Kostel Nejsvětější Trojice, pohled z hradu. Foto J. Varhaník, 2015.

Abb. 7. Rabí, Bezirk Klatovy. Kirche zur Allerheiligsten Dreifaltigkeit, Blick von der Burg. Foto J. Varhaník, 2015. něž mohly náležet tesané díly ostění střílen, by zajisté našly jiné uplatnění. Ve zdivu mladších hospodářských budov na hradě se však žádné takové druhotně použité architektonické články nevyskytují, právě tak jako v zástavbě městečka. Z toho lze usuzovat, že ostění stř́len zaniklé části opevnění byla zřejmě vyzděna $\mathrm{z}$ cihel, podobně jako je tomu u stř́len ojediněle dochovaného úseku hradebního ochozu západně od první brány (Varhaník v tisku).

A. Sedláček $(1936,17)$ otiskl zprávu bez uvedení pramene, že v roce 1505 v návaznosti na stavbu bašty a kusu zdi až k mlýnu, vybudovaných Václavem Švihovským, „přiveden byl M. Benedikt z Prahy a musili tu baštu a ten kus zdi zbořiti a Jindřich dal znovu dělati“. Z kontextu je zřejmé, že autorovi v této souvislosti šlo spíše o poukaz na neshody obou spoluvlastníků než o vysledování stavebního vývoje hradu. Na základě této kusé informace je však v literatuře často předpokládáno ovlivnění koncepce švihovského opevnění B. Riedem, či dokonce jeho přímé autorství.

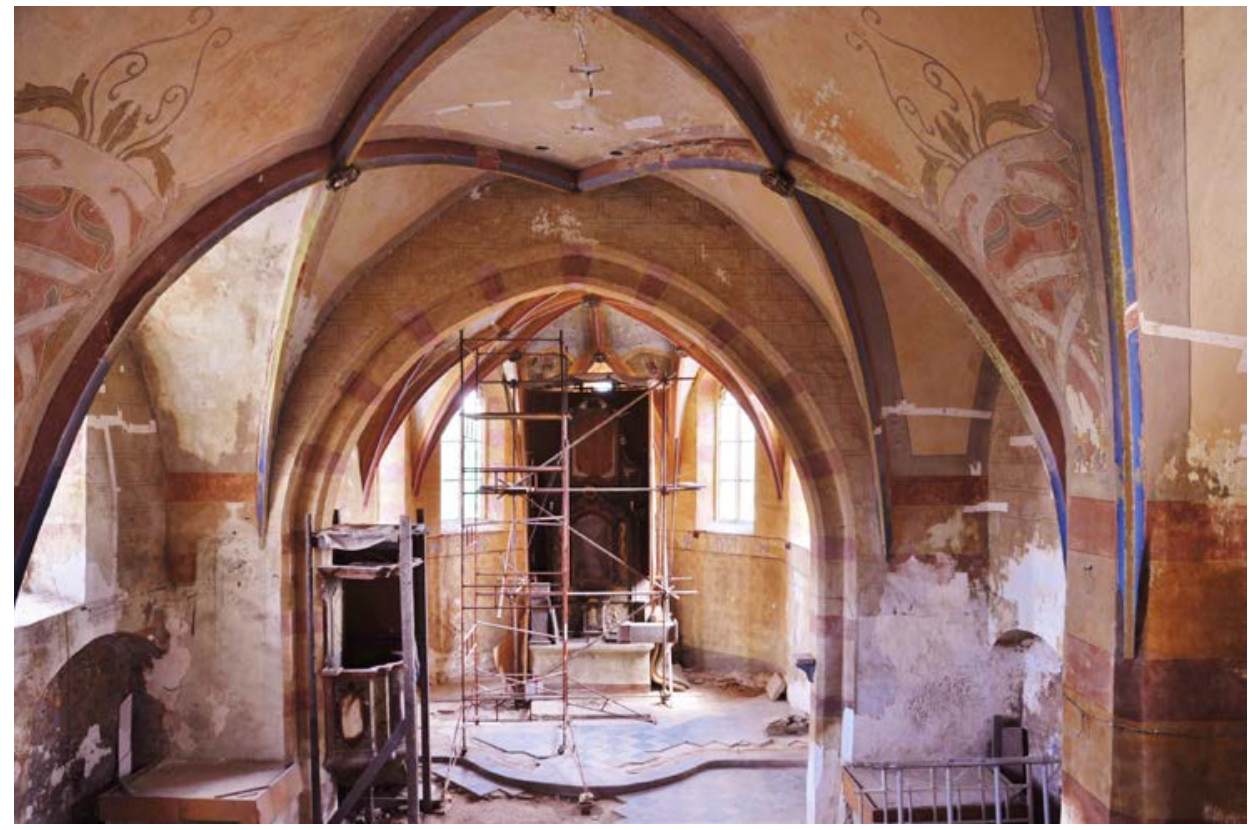

Obr. 8. Rabí, okr. Klatovy. Kostel Nejsvětější Trojice, interiér. Foto J. Varhaník, 2015.

Abb. 8. Rabí, Bezirk Klatovy. Kirche zur Allerheiligsten Dreifaltigkeit, Innenraum. Foto J. Varhaník, 2015. 


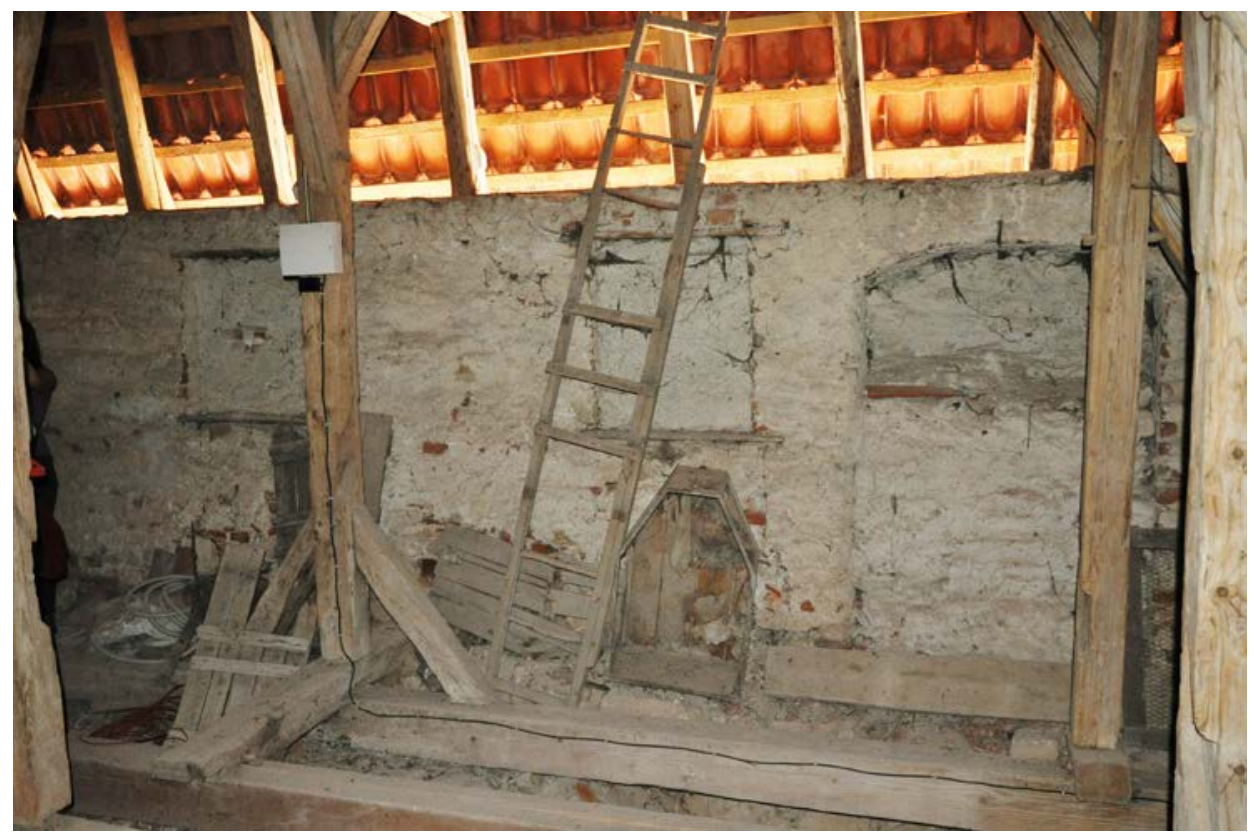

Obr. 9. Rabí, okr. Klatovy. Kostel Nejsvětější Trojice, západní štít lodi se zazděným vchodem z můstku z hradu napravo. Foto J. Varhaník, 2015.

Abb. 9. Rabí, Bezirk Klatovy. Kirche zur Allerheiligsten Dreifaltigkeit, Westgiebel des Schiffs mit zugemauertem Eingang über eine kleine Brücke von der Burg aus rechts. Foto J. Varhaník, 2015.

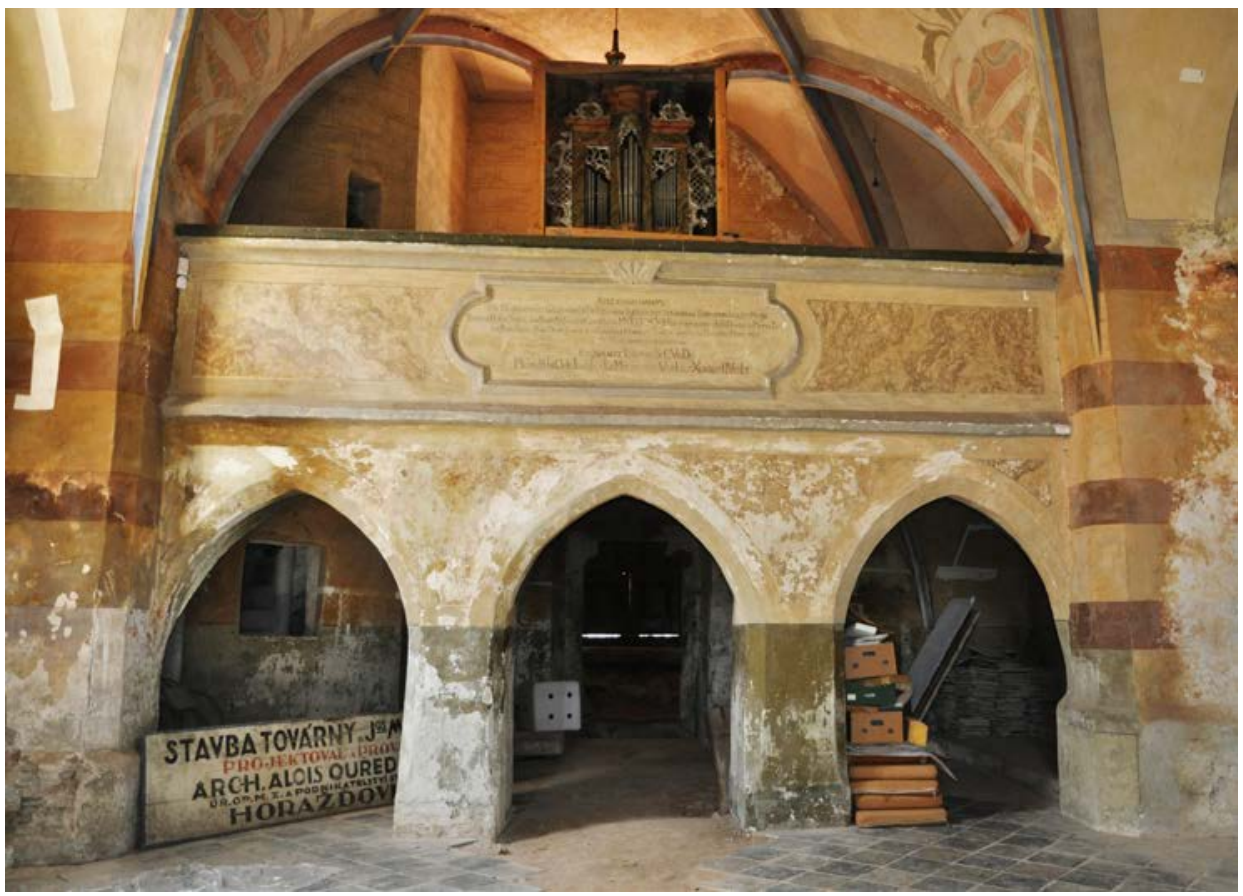

Obr. 10. Rabí, okr. Klatovy. Empora kostela Nejsvětější Trojice. Foto J. Varhaník, 2015.

Abb. 10. Rabí, Bezirk Klatovy. Empore der Kirche zur Allerheiligsten Dreifaltigkeit. Foto J. Varhaník, 2015. 


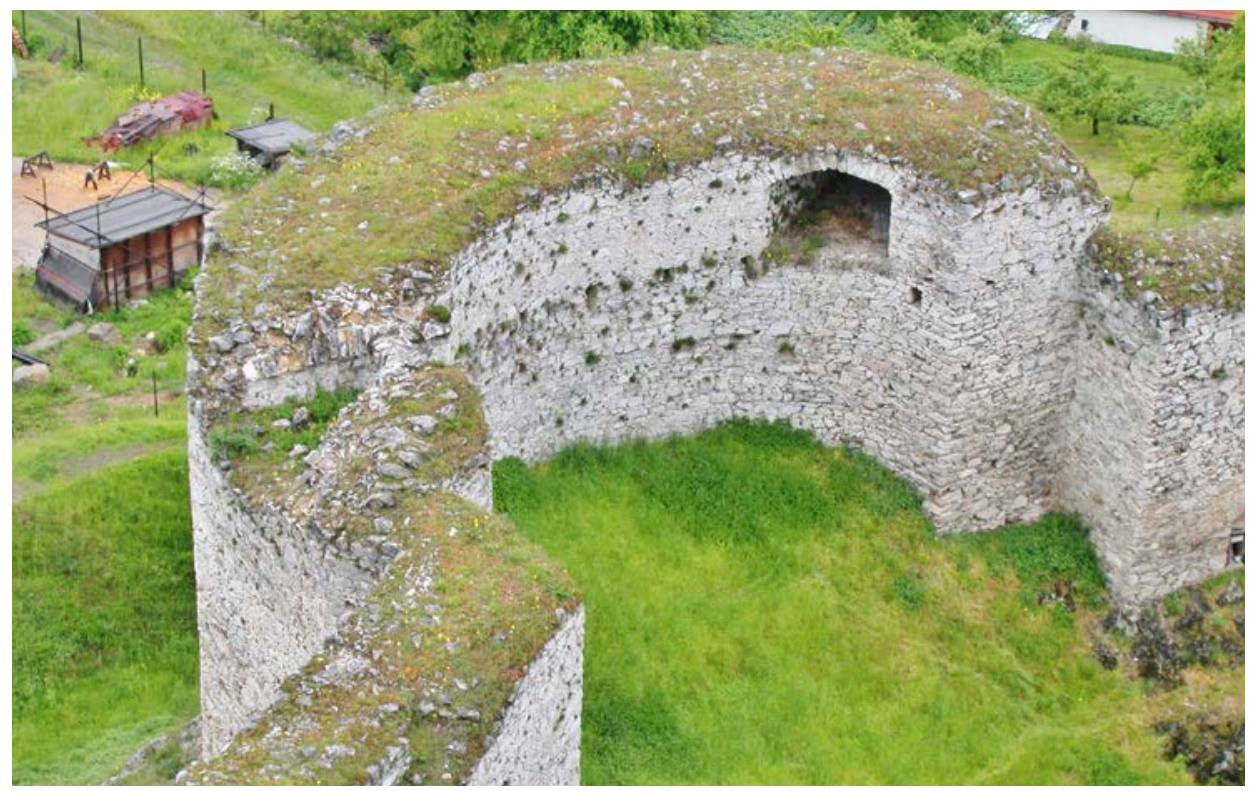

Obr. 11. Hrad Rabí, okr. Klatovy. Zevně polygonální bašta vnějšího opevnění na západní straně, k níž se kurtiny připojují takřka „na střih“. Foto J. Varhaník, 2004.

Abb. 11. Burg Rabí, Bezirk Klatovy. Von außen polygonale Bastei der äußeren Befestigung auf der Westseite, an welche die Kurtinen quasi „Kante auf Kante“ anstoßen. Foto J. Varhaník, 2004.

V reakci na tato mnohdy velice suverénní tvrzení nelze než konstatovat, že pokud Ried skutečně výstavbu švihovského opevnění nějak ovlivnil, pak vyvstává obtížně řešitelná otázka, které jeho části mu lze odůvodněně připisovat (Kuthan 2010, 321). Úvahy pokoušející se určit Riedův podíl na Švihově, jakož i jeho účast na přestavbě Rabí, jež není nijak doložena, mají charakter leckdy sice zajímavých, ale věcně zcela nedostatečně podložených spekulací (např. Kalina 2009, 147-150). Bohužel informace o Riedově účasti na Rabí pronikla též do anglického resumé významné syntetické práce o gotice v jihozápadních Čechách (Jindra-Ottová 2013, 489).

Zaniklá část opevnění švihovského hradu bývá hodnocena takřka v superlativech, zřejmě také pod dojmem předpokládaného vlivu či dokonce autorství B. Rieda (Menclová 1953, 4-5; 1972, 402; Durdík 1999, 548-549; Anderle 2013, 139). Na základě výkopu D. Menclové (2005) z roku 1951 není pochyb o kvalifikovaně rozvržené dispozici východní poloviny vnějšího opevnění s masivní baštou na východě, ovšem tloušt'ka obou jihovýchodních kurtin, oddělených poněkud menší, teprve nedávno zjištěnou baštou (Foster 2005), nepřesahovala $2 \mathrm{~m}$. Schodiště na ústupku zdiva kurtiny zde prokázáno nebylo. O vlastním provedení této nadzemní - v 17. století zbořené - části fortifikace nejsou kromě známého vyobrazení na nástěnné malbě v hradní kapli a pozdějšího Willenbergerova, dokládající menší výšku bašt a kurtin než v západní části, $\mathrm{k}$ dispozici žádné bližší informace. Již A. Sedláček $(1936,15)$ považoval za nadnesený Balbínův údaj o šířce hradeb dostačující pro dva vozy vedle sebe. Výkopem zjištěné zdivo skutečně takových rozměrů zdaleka nedosahuje, avšak nabízí se ještě jiné vysvětlení Balbínovy zprávy, že totiž při vnitřním líci alespoň některých úseků tohoto hradebního obvodu mohlo být přisypáno zemní těleso, jehož koruna by pak udané šířce mohla odpovídat. Obdobné řešení bylo již dříve využito na vnějším opevnění nepříliš vzdáleného hradu Klenová (Durdík 1999, 254-256). Vzhledem $\mathrm{k}$ jen zcela torzálně dochovanému stavu této fortifikace je třeba ponechat celou řadu otázek vztahujících se k podobě její elevace otevřených. Kromě toho poznatky z analýzy vnějšího opevnění Rabí, dokládající propastný rozdíl mezi pokročilým projektem a zkomoleným provedením (Varhaník 2005; Varhaník-Krušinová-Kyncl-Kyncl 2005), by měly nabádat při klasifikaci této pozoruhodné, avšak blíže nepoznané stavby ke zvýšené opatrnosti. 


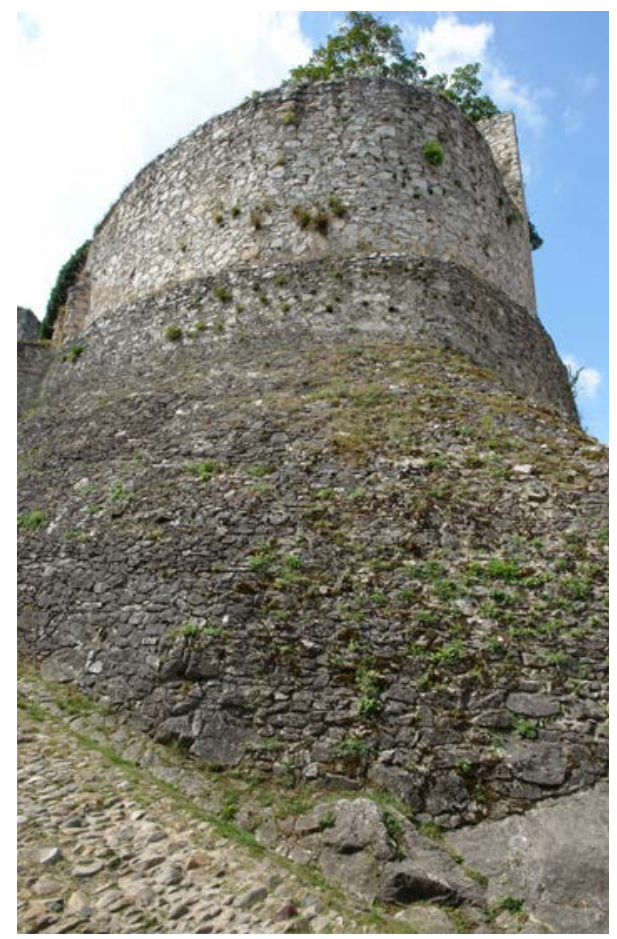

Obr. 12. Hrad Rabí, okr. Klatovy. Skarp při východním konci severního opevnění nad přihrádkem. Foto J. Varhaník, 2009.

Abb. 12. Burg Rabí, Bezirk Klatovy. Escarpe am Ostende der nördlichen Befestigung oberhalb der Zwinger. Foto J. Varhaník, 2009.

lem nasvědčujícím této skutečnosti je také absence hradu, v pozdní gotice se již poměrně běžně vyskytujících, jejichž kvalifikované provedení by vyžadovalo další kamenickou práci. $Z$ těchto důvodů je na rozdíl od Švihova prakticky nemožné se blíže vyjádřit k architektonickému vybavení nejvýznamnějších interiérů obytných budov hradu, nicméně podle uvedených indicií se zdá, že počet tesaných architektonických detailů zde nebyl velký.

Přesto oba velké hrady zajisté představovaly v dobovém kontextu honosné rezidence, což dobře dokládají lépe zachované interiéry na Švihově s klenbami bez žeber (Menclová 1953, 4; Novobilský 2007) a kvalitními nástěnnými malbami (Royt 2013, 226-231). Naproti tomu může vzbuzovat určité rozpaky klasifikace jejich podhradního osídlení jako rezidenčních měst (Šimůnek 2013, 51), nebot' to si přes snahu tehdejší vrchnosti o jejich povznesení jak urbanistické a hospodářské, tak právní, ponechalo v obou případech svůj agrární charakter hluboko do 20. století (Pelant 1988, 237-238, 275-276). Podstatně větší a významnější Horažd’ovice měly ještě roku 1619 většinu domů dřevěných (Birnbaumová 1941). Sotva lze rovněž akceptovat představu, že „,pevnost“ jak v případě Švihova, tak Rabí tvořila nedílnou jednotu s nově opevněným městem (Kalina 2009, 150), nebot' odolnost obou hradů s ohrazením jejich podhradí, resp. jeho části, samozřejmě nesnesla srovnání (Varhaník 2010, 41-42).

Sotva pochopitelné protiklady vyplývají z analýzy vnějšího opevnění hradu Rabí, budovaného z největší části Půtovými syny, zatímco jeho aktivitě můžeme přičítat nejspíše přestavbu druhé brány a prodloužení přihrádku, odkud byla př́stupná empora kostela (Varhaník 2005; Varhaník-Krušinová-Kyncl-Kyncl 2005). 
Vnější opevnění je dílem nejméně dvou mistrů, jejichž koncepční východiska byla zcela odlišná. Starší úsek na západní straně s dvojicí bašt, válcovou a polygonální, a mezilehlou kurtinou se vyznačuje kamennými schodišti na ústupcích vnitřního líce hradeb. Zatímco v obou baštách se uplatňují pečlivě opracovaná tesaná ostění tvaru ležatého protáhlého obdélníka, provedení obdobně utvářené trojice střílen v kurtině již taková pozornost věnována nebyla, přičemž kvalita provedení zřetelně klesá směrem od severu k jihu. Rozpaky vzbuzuje také připojení polygonální bašty k této kurtině takřka „na střih“, kde bylo zeslabení zdiva poněkud nekoncepčním způsobem využito pro zřízení nevelké komory se štěrbinovou stř́lnou. Do jisté míry zarážející je rovněž srovnání obou bašt - zatímco poněkud menši jižní je opatřena pravidelně rozmístěnými stř́lnami ve dvou etážích, většími komorovými ve spodní a menšími štěrbinovými v horní, polygonální bašta má, přes své impozantní rozměry, pouze dvě velké komorové střílny ve své horní části, zatímco spodní je plná, bez jakýchkoli otvorů. Je zřejmé, že již v průběhu budování této etapy výstavby vnějšího opevnění došlo k určitým změnám oproti počátečnímu záměru, které se projevily zejména nedbalým provedením ostění stř́len v kurtině, kde bylo upuštěno od kvalifikovaného kamenického zpracování. Z poněkud neorganického napojení polygonální bašty na stávající jižní kurtinu lze usuzovat, že se nejprve jen provizorně připojovala na starší hradební okruh v těchto místech, tvořený podstatně tenčí a nižší hradbou s drobnými hranolovými baštami. Naproti tomu jižní bašta s celkem osmi stř́lnami ve dvou úrovních představovala nápadný krok kupředu, který dokonce připouští úvahu, že šlo o dílo jiného mistra než v př́padě polygonální bašty, jakkoli je ostění severní stř́lny ve spodní úrovni řešeno obdobně jako v polygonální baště.

Následně však došlo k daleko závažnější změně, která přinesla radikální obrat. Ten sice nepředstavoval zásadní zlepšení opevnění po stránce kvalitativní, ale přinesl převratné řešení z hlediska koncepčního a především slohového. Neznámý zahraniční mistr, snad italského či západoevropského původu, zřejmě dobře obeznámený s renesančními teoretickými úvahami o utváření fortifikačních staveb, vyprojektoval severní část vnějšího opevnění jako osově symetrickou kompozici, v jejímž středu se měla uplatňovat rozměrná bašta parabolického půdorysu na masivním polygonálním soklu. Nejprve vzniklo západní, poté východní křídlo této fortifikace a nakonec $\mathrm{k}$ nim byla připojena střední bašta, při jejímž zakládání však došlo k odchylce od osy celé kompozice směrem k severovýchodu (Varhaník 2005, 16-22). Tento záměr byl zjevně koncipován na konkrétní terénní podmínky hradu, přičemž využil části starší fortifikace na východní straně.

Nešlo tedy o importované schéma, mechanicky na Rabí aplikované, a je proto kontraproduktivní pokoušet se najít jeho konkrétní vzor, jak namítal P. Kalina $(2009,147)$. Právě tak je ovšem kontraproduktivní shledávat italské vzory v polygonálním půdorysu severozápadní bašty rábského opevnění, který se předtím uplatnil u několika významných fortifikačních staveb v Čechách (Varhaník 2010, 41).

Východní bašta vnějšího severního opevnění hradu Rabí nad přihrádkem byla v literatuře nepř́liš vhodně charakterizována jako torion (Menclová 1972, 408, 411; Kuthan 2010, 326, 327; Anderle 2013, 129-130; Šimůnek 2013, 50). Obsah pojmu torion se pokusil definovat T. Durdík (1999, 466), podle něhož jde o „mimořádně velkou patrovou protáhlou dělostřeleckou baštu s oblým čelem pozdně gotických a raně novověkých opevněni"، Zároveň si však autor protiřrečil tím, že hned v následující větě uvádí právě severovýchodní baštu na Rabí jako nejstarší př́íklad torionu, ačkoli není patrová a nebyla vybavena pro dělostřeleckou obranu, ale výhradně pro užití ručních zbraní (Varhaník 2005, 14-15; 2010, 38). Ve skutečnosti jde pouze o poměrně plynule vedený záhyb hradby, vzniklý ve dvou etapách její výstavby, který původně neobsahoval žádné vnitřní konstrukce, což bezpečně dokládají druhotně vylámané kapsy pro zhlaví trámů na vnitřním líci zdiva. Výsledný tvar bašty, vzbuzující svými rozměry pozornost literatury, vznik1 v důsledku terénní situace nad přihrádkem. Primárním a určujícím záměrem bylo pouze přibližně čtvrteliptické zakřivení půdorysu severní hradby, podmíněné zřejmě využitím staršího zdiva, provizorně zakončené na východní straně relativně strmou stupňovitou spárou, dobře sledovatelnou jak na vnitřním, tak i vnějším líci zdiva. Na toto čtvrteliptické zakončení hradby, které 
zrcadlově odpovídá řešení opačného, západního ukončení severního vnějšího opevnění, navázal v další sezóně úsek hradby nad přihrádkem.

Hranolová vížka na západním křídle severního opevnění obsahuje jediný dendrochronologicky datovaný prvek tohoto úseku - strom, z jehož dřeva byl zhotoven nosný trám ochozu umožňujícího na vnitřní straně vížku obejít, byl smýcen v létě roku 1509 (Varhaník-Krušinová-Kyncl-Kyncl 2005, 87-88). Spojovat ve středoevropském prostředí unikátní řešení této části vnějšího opevnění Rabí s italskou cestou Půty Švihovského v roce 1487, jak nedávno připomněl J. Anderle $(2013,130)$, není bohužel možné, výstavba zde probíhala o celou jednu generaci později, za Půtových synů Břetislava a Viléma, jimž při dělení otcova majetku Rabí připadlo.

Pravděpodobně tentýž mistr byl autorem jižní části opevnění, kde se sice neuplatňují žádné bašty, ale kde bylo plánováno zřízení střeleckých komor ve dvou úrovních nad sebou, přičemž ostění spodních se mělo otvírat v rozměrném skarpu, který měl v těchto místech úpatí masivní hradby obíhat. Právě záměr výstavby skarpu, bezpečně doložený střeleckou komorou na jihozápadní straně, která předstupuje v podobě nízkého rizalitu s nelícovanými stěnami před úroveň hradby, nasvědčuje autorství téže osobnosti, jejímž dílem byl návrh osově symetrického severního opevnění. Na úpatí jeho východního okraje, mezi první a druhou branou přihrádku, byl totiž úsek mohutného skarpu vybudován. Bohužel se již asi nepodaří zjistit, zda dutina v jeho masivu, jejíž existence byla identifikována inženýrsko-geologickým průzkumem, byla kasematou, či jen velkou kavernou (Varhaník-Zavřel 2009).

S velkorysou a na středoevropské poměry mimořádně pokročilou koncepcí těchto částí vnějšího opevnění hradu nápadně kontrastuje neobyčejně zkomolená úroveň jeho provedení. Opětovně se při napojení stř̌ední bašty na západní křídlo severního opevnění vyskytlo krajně problematické řešení takřka „na střih“, které bylo již předtím realizováno na západní straně u velké polygonální bašty. Nejvíce zarážející je však okolnost, že prostorné střelecké komory převážně vůbec nebyly opatřeny stř́lnami, ale zůstaly navenek slepé pouze jako bezúčelné hluboké niky, otvírající se ve vnitřním líci hradeb. Komorové stř́ílny horní úrovně jižního úseku opevnění, jejichž stavba byla zahájena, jak dokládají svislé hrany jejich špalet, nebyly dokončeny a ještě během stavby byly vyplněny zdivem. Zatímco v případě jižní části opevnění není známo, zda byla na své koruně opatřena ochozem, u severní části opevnění to dokládá známé vyobrazení hradu od Jana Willenbergera. Jeho utváření však, na rozdíl od půdorysného rozvrhu, bylo tradiční v tom, že vrcholilo ve stř̌edoevropském prostředí obvyklým vyloženým hrázděným ochozem. Ten však nepředstavoval jedinou linii obrany - pod ním probíhal na koruně hradby další ochoz, krytý předprsní zdí se stř́lnami pro ruční zbraně, podobně jako tomu bylo na jen o málo starším částečně dochovaném úseku hradby západně od první brány hradu Švihova (Varhaník v tisku).

Zkomolení velkoryse koncipovaného opevnění představuje obtížně pochopitelný jev, a to tím spíše, že k němu docházelo podstatně dříve, než majitele hradu postihly důsledky úpadku (Holý 1960), jímž starší literatura zdůvodňovala zastavení prací (Menclová 1960, 20). Možnost, že místní zedníci, které měli majitelé hradu k dispozici, nepochopili záměr projektanta, který zřejmě nebyl po celou dobu realizace př́tomen, mohla sehrát určitou roli, ale jen do jisté míry, nebot' rozsáhlý stavební podnik musel být $\mathrm{v}$ každém př́ípadě veden přiměřeně poučenou osobou s nezbytnou praxí, jíž sice sotva mohlo být něco známo o úvahách italských renesančních architektů, ale musela být schopna alespoň rutinním a elementárním způsobem splnit svůj úkol. Napojování jednotlivých úseků fortifikace takřka „na střih“ dovoluje předpokládat, že by mohlo jít o doklad, spíše než neznalosti či neschopnosti provádějících pracovníků, snahy dosáhnout alespoň určité úspory, tedy zásahu objednatelů. Významná je v této souvislosti okolnost, že tento zřejmý nedostatek není pozorovatelný zvenčí. Zcela nepochopitelné je pak upuštění od realizace stř́len již dokončených komor v hradbách, jímž k podstatné úspoře dojít nemohlo, avšak do značné míry osudově degradovalo hodnotu nově zřizovaného opevnění. Na počátku 16. století již lze důvodně předpokládat, že nově budovaná fortifikace schopná aktivní obrany pouze na své koruně - byt' ve dvou úrovních nad sebou - se poučenějším pozorovatelům přes své impozantní rozměry musela nutně jevit jako anachronická. Paradoxně zatímco byla nově vy- 
budovaná palebná postavení dokončena v nepoužitelné podobě, či dokonce rozestavěná na jižní straně zcela zrušena, uvnitř hradu byly v severním křídle paláce pořízeny náznaky smolných nosů, resp. dolů směřujících stř́len, které však byly slepé. K obraně se jich samozřejmě nikterak využít nedalo, a měly tedy od počátku výhradně demonstrační charakter (Varhaník 2005, 68). Na Rabí se tak počal uplatňovat trend, který později podstatně poznamenal utváření četných panských sídel (Kwaśniewski 2012). Zdá se tedy, že hlavní př́ičinou zkomolení a nedokončení rábského vnějšího opevnění byl nezájem stavebníků, kteří ačkoli dobře věděli o opakovaném dobytí hradu Janem Žižkou v minulosti a posléze si dokázali opatřit projektanta, obeznámeného s nejpokročilejšími projevy italské fortifikační architektury, záhy rezignovali na důslednou realizaci jeho velkolepého záměru, stejně jako na uzavření okruhu vnějšího opevnění na východní straně. Nemůže být sporu o tom, že hrad v této podobě byl obranyschopný, ovšem rozhodně se nestal v podmínkách střední Evropy jednou z nejlépe vybavených pevností, jak uvedl J. Kuthan $(2010,329)$, ačkoli se jí při větši důslednosti stavebníků zajisté stát mohl. Ti se místo toho patrně spokojili s impozantním vzezřením hradu na pohledově nejvíce exponované severní straně a dokončení vnější fortifikace, stejně jako plnohodnotné využití již téměř dokončených partií opevnění nejspíše nepovažovali za nezbytné. S jistou dávkou opatrnosti je možné na základě těchto závěrů usuzovat, že ve své době s eventuálním obléháním hradu, které by podrobilo nové opevnění zatěžkávací zkoušce, zřejmě vůbec nepočítali.

Architektonická tvorba na základě objednávek Švihovských z Rýzmberka na konci 15. a počátku 16. století tak poněkud zvláštním způsobem zrcadlí na jedné straně nemalé ambice stavebníků a na straně druhé prozrazuje snahu o úsporná řešení, která však nebyla vyvolána až finančním úpadkem rodu (Holý 1960), ale projevovala se již překvapivě v době jeho největšího vzestupu za Půty Švihovského, jak to dokládá zejména sanktuárium ve švihovské hradní kapli či absence branek pro pěší u bran hradu Rabí. Obtížně vysvětlitelným jevem zůstává podivné zkomolení velkorysého opevnění Rabí, u něhož samotný poukaz na úspornost realizace neobstojí.

\section{Prameny a literatura}

ANDERLE, J., 2013: Hrady v jihozápadních Čechách. In: Obrazy krásy a spásy. Gotické umění v jihozápadních Čechách - Images of Beauty and Salvation Gothic Art in South West Bohemia (Jindra, P.-Ottová, M., edd.), 112-143. Řevnice - Plzeň.

BIRNBAUMOVÁ, A., 1941: Horažd’ovice. Praha, nestr.

BLÁHA, J., 2010: Českokrumlovské kryté chodby. In: Český Krumlov, od rezidenčního města k památce světového kulturního dědictví, 149-174. Český Krumlov.

ČERVENKA, V., 2015: Poznámky k heraldickým památkám v kostele v Nezamyslicích, Památky západních Čech V, 44-47.

DURDÍK, T., 1999: Ilustrovaná encyklopedie českých hradů. Praha.

FOSTER, L., 2005: Švihov - hrad, vnější opevnění - jihovýchodní úsek. Archeologické sondy. Nálezová zpráva ulož. v NPÚ ÚOP v Plzni.

JINDRA, P.-OTTOVÁ, M., edd., 2013: Obrazy krásy a spásy. Gotické umění v jihozápadních Čechách Images of Beauty and Salvation. Gothic Art in South West Bohemia. Řevnice - Plzeň.

HOLÝ, V., 1960: Růst a rozklad rodového majetku Švihovských z Rýzmberka a pánů z Rožmitálu, Minulostí Plzně a Plzeňska III, 45-79.

HOSTAŠ, K.-VANĚK, F., 1900: Soupis památek historických a uměleckých v království českém 12. Politický okres sušický. Praha.

CHLÍBEC, J., 1983: Náhrobek Půty Švihovského a jeho symbolika v kontextu pozdně gotické náhrobní plastiky, Umění XXXI, 27-33.

CHLÍBEC, J.-ROHÁČEK, J., 2011: Sepulkrální plastika jagellonského období v Čechách. Figura a písmo Sepulkralplastik in der Jagiellonenzeit. Praha.

KALINA, P., 2009: Benedikt Ried a počátky záalpské renesance. Praha.

KAŠIČKA, F., 2011: Dlouhá chodba třeboňského zámku a její stavební počátky - Der Lange Gang des Schlosses in Třeboň und seine baulichen Anfänge. In: Dějiny staveb. Sborník př́spěvkủ z konference Dějiny staveb 2010, 51-57. Plzeň. 
KOVÁČ, P., 1989: Rekonstrukce pozdně gotického sousoší z Rabí - Rekonstruktion spätgotischer Statuengruppe aus Rabi, Umění XXXVII, 289-299.

KUTHAN, J., 2010: Královské dílo za Jiř́ího z Poděbrad a dynastie Jagellonců. Díl I. Král a šlechta. Praha.

KWAŚNIEWSKI, A., 2012: „Fortezza verso Residenza“. Nevojenské funkce fortifikací ve struktuře zámeckého areálu ve střední Evropě (zejména s ohledem na Slezsko) - „Fortezza verso Residenza“. Nicht-militärische Funktionen von Fortifikation in der Struktur von Schlossarealen im frühneuzeitlichen Mitteleuropa (besonders mit Rücksicht auf Schlesien), Svorník 9/2011, 5-36.

LANCINGER, L.-LÍBAL, D., 1970: Hrad Rabí, stavebně historický průzkum, SÚRPMO, ulož. na ústředním pracovišti NPÚ v Praze.

LANCINGER, L.-LÍBAL, D.-MUK, J., 1974: Hrad Rabí, Kostel Nejsvětější Trojice, stavebně historický průzkum, SÚRPMO, ulož. na ústředním pracovišti NPÚ v Praze.

LANCINGER, L.-MUK, J., 1975: Hrad Švihov, stavebně historický průzkum, SÚRPMO, ulož. na ústředním pracovišti NPÚ v Praze.

LAVIČKA, R., 2015: Nový pohled na stavební vývoj kostela Nanebevzetí Panny Marie v Nezamyslicích A new view on the architectural development of the Assumption church at Nezamyslice, Památky západních Čech V, 27-43.

MENCL, V., 1960: Vývoj středověkého portálu v českých zemích, ZPP 20, 8-26, 112-153.

MENCLOVÁ, D., 1953: Švihov, státní hrad a městečko. Praha.

- 1960: Rabí, státní hrad a památky v okolí. Praha.

- 1972: České hrady 2. Praha.

- 2005: Zpráva o výkopu na hradě Švihově, provedeném ve dnech 11.-28. listopadu 1951. In: Varhaník, J., Vnější opevnění hradu Rabí. I. část - Die äussere Befestigung der Burg Rabí, PRP 12, č. 1, 33-35.

MUDRA, A., 2013: Středověké interiéry a vybavení kostelů v jihozápadních Čechách. In: Obrazy krásy a spásy. Gotické umění v jihozápadních Čechách - Images of Beauty and Salvation Gothic Art in South West Bohemia (Jindra, P.-Ottová, M., edd.), 146-157. Revnice - Plzeň.

NOVOBILSKÝ, M., 2007: Zamyšlení nad vývojem jádra hradu Švihova - Betrachtungen über die Entwicklung der Kernburg von Švihov. In: Dějiny staveb. Sborník příspěvků z konference Dějiny staveb 2006, 225-250. Plzeň.

OTTOVÁ, M., 2013: Objednavatel, dílna a styl: Gotické sochařství v jihozápadních Čechách. In: Obrazy krásy a spásy. Gotické umění v jihozápadních Čechách - Images of Beauty and Salvation. Gothic Art in South West Bohemia (Jindra, P.-Ottová, M., edd.), 268-282. Řevnice - Plzeň.

PELANT, J., 1988: Města a městečka západočeského kraje. Plzeň.

PEŠINA, J., 1954: Hradní kaple na Švihově. Praha.

ROYT, J., 2013: Středověká desková a nástěnná malba v jihozápadních Čechách. In: Obrazy krásy a spásy. Gotické umění v jihozápadních Čechách - Images of Beauty and Salvation. Gothic Art in South West Bohemia (Jindra, P.-Ottová, M., edd.), 170-241. Řevnice - Plzeň.

SEDLÁČEK, A., 1936: Hrady, zámky a tvrze království českého IX. Praha.

ŠIMU゚NEK, R., 2013: Reprezentace české středověké šlechty - The Representation of Czech Medieval Nobility. Praha.

VANĚK, F.-HOSTAŠ, K.-BOROVSKÝ, F. A., 1899: Soupis památek 7. Politický okres klatovský. Praha.

VARHANÍK, J., 2005: Vnější opevnění hradu Rabí. I. část - Die äussere Befestigung der Burg Rabí, PRP 12, č. 1, 15-36.

- 2010: Místo hradu Rabí mezi časnými renesančními importy - Die Verortung der Burg Rabí unter der frühen Renaissanceimporten. In: Moravskotřebovský zámek, 37-43. Moravská Třebová.

- 2015: Původ okénka empory zvíkovské kaple - Der Ursprung des Emporenfensterchens in der Burgkapelle von Zvíkov, Svorník 13/2015, 111-116.

- v tisku: Pozůstatky hradebního ochozu na hradě Švihově, Svorník 14/2016.

VARHANÍK, J.-KRUŠINOVÁ, L.-KYNCL, J.-KYNCL, T., 2005: Vnější opevnění hradu Rabí (II. část) Die äussere Befestigung der Burg Rabí, PRP 12, č. 2, 55-96.

VARHANÍK, J.-ZAVŘEL, J., 2009: Hrad Rabí - doposud opomíjené poznatky ze starších průzkumů z Geofondu Praha - Die Burg Rabí - bislang übergangene Erkennnisse aus älteren Untersuchungen des Tschechisches Geologischen Dienstes Geofond Prag, AH 34, 725-732.

ZÁRUBA, F., 2013: Rabí, hradní kostel Nejsvětější Trojice. In: Obrazy krásy a spásy. Gotické umění v jihozápadních Čechách - Images of Beauty and Salvation Gothic Art in South West Bohemia (Jindra, P.Ottová, M., edd.), 99-100. Řevnice - Plzeň.

- 2013a: Švihov, hradní kaple Panny Marie. In: Obrazy krásy a spásy. Gotické umění v jihozápadních Čechách - Images of Beauty and Salvation Gothic Art in South West Bohemia (Jindra, P.-Ottová, M., edd.), 103-104. Řevnice - Plzeň. 


\section{Zusammenfassung}

\section{Vorder- und Kehrseite der Repräsentation der Schwihaus von Riesenberg an der Wende von der Gotik zur Renaissance}

Kunstwerken, die an der Wende von der Spätgotik zur aufkommenden Renaissance von Angehörigen des führenden westböhmischen Adelsgeschlechst Schwihau von Riesenberg in Auftrag gegeben worden waren, wurde in der Literatur bereits früher schon eine beträchtliche Aufmerksamkeit gewidmet. Puta Schwihau von Riesenberg ( $\dagger 1504)$ hatte als erster den großzügigen Umbau der beiden wichtigsten Familienburgen Schwihau (Švihov) und Rabí in Angriff genommen, wobei er an beiden eine neue Kapelle errichtete. Seine Söhne haben mit der Befestigung dieser Burgen dann weitergemacht. Die Schwihaus von Riesenberg waren im genannten Zeitraum Auftraggeber von zahlreichen qualitativ hochstehenden Kunstwerken. Offenbar unter diesem Eindruck kommen in der bisherigen Literatur bisweilen sehr übertriebene Beurteilungen ihrer Bauproduktion vor, besonders was die Befestigung beider genannten Burgen betrifft. Bei einer etwas nüchterneren Betrachtung wirkt das Niveau dieser Bauten jedoch nicht ganz eindeutig und ist nicht einfach, ja bisweilen gar von verblüffenden Widersprüchen geprägt.

Die Architektur der beiden Burgkapellen ist verhältnismäßig bescheiden und geht nicht über den Durchschnitt der Produktion jener Zeit hinaus, das Sakramentshäuschen der Kapelle auf Burg Schwihau ist gar auffällig einfach. Aufgrund einer knappen Erwähnung in A. Sedláčeks Werk wird in der Literatur eine Beteiligung bzw. direkte Urheberschaft von B. Ried an einem Teil der Befestigung von Burg Schwihau angenommen, obwohl eine Spezifizierung seines eventuellen Anteils problematisch ist.

Rieds Beteiligung an Burg Rabí ist keinesfalls belegt, und die Gestaltung der äußeren Befestigung deutet noch nicht einmal darauf hin. Ihr Westteil ist offenbar das Werk eines böhmischen Meisters, der auf der Mittelachse konzipierte Nordteil hingegen verrät die Beteiligung eines italienischen bzw. westeuropäischen Bauprojektplaners, der mit den theoretischen Arbeiten der renaissancezeitlichen Architekten der zweiten Hälfte des 15. Jahrhunderts vertraut war, was für Mitteleuropa einzigartig ist. Der auf dem Westflügel dieser Befestigung stehende kleine Prismenturm wird chronologisch durch das Dendrodatum 1509 bestimmt. Durch die Realisierung des Nordteils wurde die Befestigung jedoch bis zu einem solchen Grad verstümmelt, dass die Schießkammern nach außen hin nicht offen waren, sondern geschlossen blieben. In ähnlicher Weise wurde am Südteil der äußeren Befestigung das obere Niveau der Schießkammern nicht fertiggestellt, auch hat man an ihrem Fuß keine Escarpe ausgeführt. An der Ostseite wurde die äußere Ringmauer nicht fertiggestellt. Trotzdem war die Burg sicherlich verteidigungsfähig, jedoch deuten diese unübersehbaren Unzulänglichkeiten darauf hin, dass es den Bauherren beim Bau der mächtigen Befestigung eher um Repräsentation als um die konsequente Errichtung einer vollwertigen Festung ging.

Das aufgrund der von den Schwihaus von Riesenberg Ende des 15. und Anfang des 16. Jahrhunderts in Auftrag gegebene architektonische Werk spiegelt einerseits die nicht gerade geringen Ambitionen der Bauherren wider und verrät andererseits, dass man um sparsame Lösungen bemüht war. Diese waren jedoch nicht durch den finanziellen Niedergang des Adelsgeschlechts hervorgerufen worden, zu dem es später gekommen ist, sondern kam überraschenderweise bereits in einer Zeit zum Ausdruck, als das Geschlecht unter Puta Schwihau seine größte Blüte erlebte. Ein nur schwer zu erklärendes Phänomen bleibt die befremdliche Verstümmelung der großzügig angelegten Befestigung Rabí, bei welcher ein Verweis auf die Sparsamkeit der Realisierung als Erklärung allein nicht ausreicht.

JUDr. Jiří Varhaník, Orlík nad Vltavou 26, 39807 Orlík nad Vltavou, Česká republika, jiri.varhanik@gmail.com 
